\title{
Moldovan Institutions That Carry out Complex Measures to Capitalize and Protect the Architectural Heritage
}

\author{
Viorica Ursu, Natalia Chiriac, Ina Bostan \\ Department of Engineering, Law and Real Estate Valuation, Technical University of Moldova, Chișinău, Republic of Moldova \\ Email: viorica.ursu@dp.utm.md, natalia.chiriac@dp.utm.md, ina.bostan@dp.utm.md
}

How to cite this paper: Ursu, V., Chiriac, N. and Bostan, I. (2021) Moldovan Institutions That Carry out Complex Measures to Capitalize and Protect the Architectural Heritage. Open Access Library Journal, 8: e8206.

https://doi.org/10.4236/oalib.1108206

Received: November 18, 2021

Accepted: December 19, 2021

Published: December 22, 2021

Copyright $\odot 2021$ by author(s) and Open Access Library Inc.

This work is licensed under the Creative Commons Attribution International License (CC BY 4.0).

http://creativecommons.org/licenses/by/4.0/

(c) (i) Open Access

\begin{abstract}
Every country and every nation have had, has, and must continue to have a cultural heritage, which represents an expression of their historical and cultural values, and expresses general, national interest, which often contributes to the establishment of the values of universal culture; which must be protected by the state, through its competent institutions, through clear, complete legislation and without gaps in interpretation. The purpose of this article is to identify the authorities, institutions, or bodies of the Republic of Moldova involved in the protection of the cultural heritage, to analyze the general areas of responsibility, and to specify, where necessary, the relations between them, to determine the relations of subordination or collaboration. Although there are a large number of responsible institutions involved in the cultural heritage management process, we still notice the lack of efficient management and the low capacity to exploit the cultural heritage. The low level of management at the central and local level, as well as the lack of cooperation between ministries, local public administration agencies, cadastral agencies and civil society is the reason for the inefficiency of public heritage management.
\end{abstract}

\section{Subject Areas \\ Culture, Law \\ Keywords \\ Heritage, Architectural Heritage, Protection, Conservation, Restoration, Institutions, Competencies, Public Authority}

\section{Introduction}

"Humanity is in a process in which, gradually, the distances between the peoples 
will be reduced. We must also fit, as Romanians, entering with our spiritual dowry in the great hora of the nations of the European continent and all humanity, just as the advanced states have framed themselves in the processes of rapprochement and unification, keeping their own features" ([1], p. 17).

Each state more or less distinctly protects all the assets regardless of their legal form of public or private property. And the protection of heritage must be done regardless of the criteria for its classification: cultural heritage and natural heritage, movable and immovable, material and intangible ([2], p. 9).

The preservation and protection of the built historic monuments are the duty of the entire community because the cultural heritage marks the identity and cultural originality of each people. In such circumstances, we consider it opportune to elucidate which public authorities in the Republic of Moldova have competencies, in the light of the normative acts in force, to protect the architectural heritage, which constitutes the cultural heritage that has a special value and which is representative for each people, while expressing the level of development of the society.

This paper aims to analyze the situation in the Republic of Moldova regarding the authorities, institutions and bodies involved in the protection of cultural heritage. Given the purpose of the study, the following objectives were outlined:

1) identification of the authorities, institutions or bodies of the Republic of Moldova involved in the protection of cultural heritage;

2) identification of the normative framework that regulates the activity of the above-mentioned institutions;

3) determining the competences and general areas of responsibility of the institutions in the field of protection, safeguarding and management of the architectural heritage;

4) elaboration of conclusions and recommendations, which are meant to contribute to the strategic understanding of the current situation and to the drawing of masterful recommendations in the field of architectural heritage in the Republic of Moldova.

In the local legal literature, the problem of institutions in the Republic of Moldova that implements complex measures to capitalize on and protect the architectural heritage is not practically studied, although some of its aspects have become the subject of scientific research. However, most of the works refer to the general issues of protection of the cultural heritage, but not all aspects related to this subject are addressed. However, we cannot fail to appreciate the study of local specialists in this field: Ploșniță E. [2], Comendant Vasile [3], Belecciu Ştefan [4], Dulschi I. [5] etc. In fact, along with a rich doctrinal bibliography, the legislation of R.M. which regulates the subject under investigation has also been analyzed.

To substantiate the proposed research, the following research methods were mainly used: the historical method, the quantitative method, the scientific method, the logical method and the comparative method. 
Given the objective of this research, the article was divided into 8 sections, which reflect the analysis of the legislation of the Republic of Moldova on the issues addressed, research in the field at the current stage of development, and the opinions of the authors. The introductory part of the article is the scientific argumentation of the research topic, made by exposing the topicality and importance of the research topic, the degree of research, the purpose and objectives proposed for implementation. In Sections 2-7, the authorities, institutions or bodies of the Republic of Moldova and their attributions in the field of protection of the architectural cultural heritage are analyzed in detail. And Section 8 has the conclusions that have been drawn from the research.

All the actions of the state, to protect the architectural heritage, constitute a set of measures having a scientific, legal, administrative, financial, fiscal, and technical character, meant to ensure the identification, research, inventory, classification, conservation, security assurance, maintenance, restoration and enhancement of the national cultural heritage to have access to democratic culture and the transmission of this heritage to future generations ([3], p. 101).

The Law on the protection of monuments, the normative act that determines the special peculiarities of monument protection, establishes that the protection of monuments by the state includes the provision and insurance of the works of record keeping, studying, highlighting, saving, protecting, preserving and restoring; expansion of the material base; the use and accessibility of monuments for various investigations in the process of training and propagation [6].

The Parliament, the Government, the district, municipal, city, and communal councils, the presidents of districts, and mayors are responsible for exercising the duties of protecting the architectural patrimony, according to this Law [6]. The Constitution of the Republic of Moldova [7], in Title II, chapter III, article 59, tells us that "the protection of the environment, the conservation and the protection of historic and cultural monuments is an obligation of every citizen".

\section{The Parliament}

The Parliament is the supreme representative body of the people of the Republic of Moldova and the sole legislative authority of the state. Thus, following the provisions of art. 11 of the Law on the protection of monuments, the competencies of the Heritage are established, related to the protection of historical monuments, namely: [6]:

1) The State policy in the field of recording, studying, highlighting, saving, protecting, preserving, and restoring the monuments that constitutes the cultural and natural heritage. The state policy in this economic and social sector must belong- or medium-term, group all types of activities, all the groups that are interested in developing these activities, but all of them as a whole must start with a simple idea: heritage received as inheritance must be preserved, protected and restored, because the sole purpose of all these activities must be one-the trans- 
mission of this cultural heritage to our descendants. And last but not least, to identify the financial sources necessary to carry out all the activities listed above.

It is important to define the actions that can be achieved within the framework of the state policy. Thus, the draft law on the protection of historical monuments regulates some terms of reference ([8] [9], p. 402):

a) protection is a set of measures of scientific, legal, administrative, financial, fiscal, and technical character, meant to ensure the identification, research, inventory, classification, the establishment of the zone of protection, recordkeeping, guarding and maintenance, design, and operation of interventions, prevention of destruction/degradation/mutilation, consolidation, conservation/restoration, capitalization of historical monuments, protection/regeneration of their historical-architectural environment, integration of historical monuments in the socio-economic and cultural life of the local communities, etc.

b) repair is a set of works (scientific research, design, and operation of the projected interventions) carried out to maintain the protected building in a state of exploitation, without modifying its historical characteristics.

c) conservation is a set of works (scientific research, design, and operation of the projected interventions) carried out to prevent the worsening of the state of the historical monument or to remedy a worsening already produced, including through consolidation works (of temporary or lasting character), without modifying the architectural and structural characteristics of the monument found at the time of its closure.

d) restoration is a set of works (scientific research, design, and operation of the projected interventions) carried out to highlight, preserve and strengthen the historical-cultural value of the protected building, including by restoring its physical and functional integrity, including by remedying some modifications/alterations suffered in time.

2) The approval of the Register of Monuments. The Register of Monuments protected by the state of the Republic of Moldova [10] is a list of monuments taken under the protection of the state, approved by the Parliament's decision no. 1531-XII together with Law no. 1530-XII on the protection of monuments of the Republic of Moldova from June 22, 1993. The Law was only published in the Official Gazette no. 1 of 1994, but it did not include the Register, which was published much later, on 2 February 2010. This 17-year delay has deprived the historic monuments of the right to be protected by the state. From the moment of publication in the Official Gazette, it provides a basis of legal protection from the state through its executive institutions and ensures the record, inventory, classification of the national heritage [11].

However, it should not be confused with the National Archaeological Register or that of monuments protected by the state, which are different lists targeting only certain compartments of cultural heritage, drawn up based on separate laws. The complete list is maintained and updated periodically by the Ministry of Culture of the Republic of Moldova, but before the amendments enter into force, 
they must be approved by the Parliament. In 2021, the Register contains 5465 monuments. They are classified by district, type (archaeological, architectural, historic, folk architecture, art, and technology), and importance (local or national) [12].

3) Approval of the State Programme on the protection, conservation, and restoration of monuments,

4) Financing this Programme and granting non-reimbursable subsidies from the state budget.

Being the body of the legislative power, the Parliament has a leading and very important role, namely in approving all normative acts in the country regarding the protection of the national cultural heritage, including the architectural one. Being the legislative power in the country, it is meant to contribute specifically to the formation of a legal, clear and explicit foundation in this important segment of the state. We do not deny the fact that much was done at the initial stage, namely by this body, but much remains to be done.

For example, a non-compliance deduced from the legislation of the Republic of Moldova is the inappropriate role of the Parliament in approving the Register of Historical Monuments as a way of establishing a system of protection of specific objects. Therefore, since the adoption of the Register by the Parliament, several monuments have been demolished. The process of large-scale demolition slowed only when the minutes of individual liability in cases of damage to cultural heritage began. It would be fair for the Ministry to be responsible for the procedures for classifying monuments. The difficulties of the procedure for declassifying the monuments have the effect of demolishing them, either illegally or legally. If the Parliament follows this procedure, the monuments to be protected will not be fully protected, and the individual protection of each monument will be longer and even more difficult. We note that keeping the downgrading procedure under the Parliament's responsibility seems to be able to protect the protected monuments to a limited extent, making the process of protecting assets that deserve to be included in the register even more difficult and lengthy.

Another non-compliance would be the complicated procedure of registration in the Register by establishing lists that are only regularly updated, instead of adopting a listing formula based on the individual inclusion, by offhand decision (preferably ministerial decisions), of the objectives that need legal protection. We recommend the creation of some mechanisms to allow the inclusion of individual objectives/goods, rather than periodic lists.

\section{The Government}

The Government is the public authority that represents and exercises the executive power in the Republic of Moldova [13]. To protect and capitalize on the architectural heritage, the Government exercises the following attributions:

1) Drawing up the Register of Monuments,

2) Drawing up the state Programme on the protection, conservation, and res- 


\section{toration of monuments,}

\section{3) Financing this Programme from the state budget [6].}

The powers for the maintenance, use, and placement of the objects and objectives with a special value of the national cultural heritage are established, at the proposal of the Government, by the Parliament, based on the opinions of the independent commissions of experts, taking into account the interests of the integrity of the historically constituted collections, their storage conditions and the possibilities of access to them [14].

Namely, the Government is responsible for the execution of the normative acts approved by the Parliament and the verification of their execution in the field of protection of the national heritage. Here we are faced with the problem of nonexecution or partial execution. Or having the tasks listed above, they don't always monitor them.

\section{The Ministry of Culture of the Republic of Moldova}

The Ministry of Culture of the Republic of Moldova is the central specialized public authority that has the attributions of execution of policies, strategies, and specific norms on the protection of the national cultural heritage [11].

At the same time, we would like to mention that this public authority coordinates and monitors at the national level, the activities of the state institutions with attributions in the implementation of strategies, programs, and projects for the protection of the elements of the cultural heritage, the process of implementing the legislation on the protection of the national cultural heritage. It simultaneously, ensuring the fulfillment of the commitments assumed through the international treaties on the protection of the cultural heritage at which the Republic of Moldova is part of and prepares young specialists in the field, including through the specialized education system at the pre-university and university level ([3], p.103).

Regarding the ministry's attributions to administer and protect the architectural heritage, V. Comendant, who generalized the spectrum of these duties, established that it is the competence of the Ministry to elaborate and approve various regulations on the profile of the national cultural heritage, files, certificates of recognition of merits in the given field, the elaboration of approvals for the documentation on the location and realization of monuments, the elaboration of specific norms and methodologies, as well as monitoring the compliance with the legal provisions in the field ([3], p.103).

To fulfill its duties in the field of cultural heritage within the Ministry of Culture, the Cultural Heritage Directorate activates which actively ensures and promotes strategies and policies, drafts laws, regulations, and public policies in the field of cultural heritage. Also, the Directorate ensures the organization and coordination of the activity regarding the protection, conservation, restoration, and capitalization of the national cultural heritage.

Thus, establishing the main competencies in the field of architectural heritage 
protection, we can conclude that this Ministry is and remains one of the most important links in the chain of institutions that are responsible for the protection of the national heritage and all the draft regulations in the field researched by the authors. These are later transmitted to the Parliament for analysis and approval. This is where it is necessary to create projects that contain rules aimed at solving and elucidating the problems in this sector, and these solutions should be real and applicable in practice.

At different times, the experts of the Ministry of Culture of Moldova, responsible for drafting the law in the field of cultural heritage protection received numerous recommendations from various national and foreign bodies, to determine their clear trajectories in the formation of bills targeting this state. Unfortunately, not all of them have been taken into account and this fact subsequently leads to multiple changes, which in fact should be a working tool, and not a simple homework. It is welcome to develop a Heritage Code of the Republic of Moldova, which would include all the rules regarding cultural heritage, as well as its protection.

The Government has created structures that have as their basis in the activity the protection and preservation of monuments. Among them is the National Council of Historical Monuments, which constitutes a specialized body in the field of state protection of historic monuments. Among the most relevant tasks of the Council provided for by the legal framework, we note [15]:

1) Examines the draft national strategy for the protection of historic monuments and proposes its approval;

2) Proposes the approval of methodologies, conventions, norms, and regulations in the field of protection of historic monuments,

3) Notifies the proposals regarding the classification, in the National Register of Historic Monuments, of the buildings, ensembles of buildings andlor built-up areas;

4) Notifies the documentations with proposals for interventions (conservation, consolidation, restoration, rehabilitation, systematization/arrangement of afferent land, etc.) on the real estate with the status of a protected monument of the national category (constructions and related land) and in their protection areas;

5) Proposes historical monuments to be included in the List of World Cultural and Natural Heritage, as well as in the List of World Heritage in Danger, kept by UNESCO.

Some efforts have been made to strengthen the legal role of the National Council of Historic Monuments notification and to improve the procedure for approving/authorizing the projects on monuments and protected areas, but confusion and hesitation still persist. This is mainly due to the difficulty of recognizing the fact that the National Council, as an advisory body of the ministry, cannot fulfill the task of issuing administrative acts with external relevance, i.e. acts that have an impact on citizens' rights. This task should be placed under the obligation of a specialized department of the Ministry of Culture of the Republic 
of Moldova.

\section{The Agency for Inspection and Restoration of Monuments}

Another specialized institution subordinated to the Ministry of Culture, which has as its main task the inspection of monuments of history, art, and architecture is the Agency for Inspection and Restoration of Monuments (AIRM). The present institution was established based on the Government's Decision no.1114 on 25.09.2006, to establish an efficient control in the field of restoration and inspection of monuments of history and culture, bringing their documents following UNESCO's usages, creating a public digital database of monuments [16].

The Agency became operational and has been able to appraise the state of the culture in 2010 when Order no.232 on 02.08.2010 on the approval of the Regulation of the Agency for Inspection and Restoration of Monuments was issued [17]. According to this order, the Agency for Inspection and Restoration of Monuments performs the following basic functions:

1) Coordinates and controls the application, based on the legislation in force in the Republic of Moldova, of UNESCO's and Council of Europe's documents on the protection, conservation, and enhancement of historic monuments, controls the activities related to the protection, conservation, restoration and enhancement of the immovable cultural heritage; establishes the priority directions of activity in the field; determines the collaborative relations with the specialized creative unions. Inspects monuments under the official protection of central and local public authorities, including their related protection zones.

2) Inspects monuments under the official protection of central and local public authorities, including their related protection zones.

3) Carries out the on-site inspection of historic monuments, of the intervention sites on them; draws up minutes on the contraventions detected; draws up service reports in this regard; submits to the Ministry of Culture proposals for the solution of the problems that have arisen.

4) Supervises the observance of the legislation of the Republic of Moldova in the field of protection, conservation, restoration, and enhancement of the monuments inscribed in the Register of Monuments of the Republic of Moldova protected by the state and approved by the Decision of the Parliament of the Republic of Moldova no. 1531-XII of June 22, 1993, as well as in the registers of monuments of local importance approved by acts of local public administration authorities.

5) Supervises the execution of works of conservation, restoration, and enhancement of historical buildings with monument status managed by institutions subordinated to the Ministry of Culture.

6) Supervises the performance by the local public administration authorities of the attributions established by the legislation in force in the field of recordkeeping, protection, conservation, restoration, and enhancement of the historic monuments of national and local importance. 
7) Analyzes the causes of violations committed by owners with any real property rights over monuments of the attributions established by the legislation in force in the field of historic monuments and take the necessary measures to liquidate the violations detected.

8) Carries out jointly with the central and local public administration authorities in the field of construction the emergency measures to save the historic monuments in the process of degradation or a state of ruin.

9) Identifies the historic buildings with a special patrimonial value and submits to the Ministry of Cultures proposals regarding their registration in the Register of monuments protected by the state. Controls the observance of the exploitation conditions and the provisions of the obligations for the protection of monuments issued by the central and local public administration authorities to the managers and owners of historical buildings with the status of a monument of national and local importance.

10) Collaborates with foreign state authorities and international organizations in the established field of activity.

\section{The Local Public Administration Authorities}

The local public administration authorities are established under the law to satisfy the needs of a territorial administrative community, being responsible for objects of the cultural heritage in the respective locality. Each territorial administrative unit, for sure, has in its local heritage the jewels of the national culture, which represent that pride, which can and must be left as a legacy to their descendants. We all know that the education to protect the architectural heritage begins at home, in people's hometown. There they become acquainted with the history of their homeland, the history of historical and cultural constructions, the construction, restoration and reconstruction, the activity of famous architects who built these local relics, but also with the activity of current protection.

According to the Law on local public administration, the local councils decide on the legal acts of the administration regarding the assets of the public domain of the village (commune), city (municipality), as the case may be, as well as on the public services of local interest, under the law. They also decide on the legal acts of the administration or disposition regarding the assets of the private domain of the village (commune), the city (municipality), as the case may be, under the law [18]. In the light of the above, we find it necessary to regulate more thoroughly the competencies and responsibilities of these bodies regarding the administration of the historic-cultural heritage that is at their balance.

However, we note that, unlike the normative act that includes a general regulation in the field, in another normative act, if it has a special character, the attributions of the local public authorities are regulated in more detail. Therefore, according to the Law on the Protection of Monuments, the district, municipal, city, and communal councils to protect the cultural heritage have the following attributions: [6] 
1) Drawing up the Register of monuments of local importance,

2) Drawing up Programs on the protection, conservation, and restoration of monuments of local importance, the financing of these programs, and granting non-reimbursable subsidies from local budgets.

To carry out the above-mentioned programs, the local public administration authorities must provide in the annual budgets means for financing or co-financing the activities of safeguarding the elements of the cultural heritage, granting of non-reimbursable subsidies from the local budgets ([3], p.104). The real situation is different, in many administrative-territorial units in the country this condition is not met due to insufficient financial resources from the local budget and the limited economic potential for development.

There are directions for culture and architecture that have the aim to develop policies for the protection and promotion of the cultural heritage, practically in each district and municipality subordinated to the local public administration. In this context, we consider it opportune to exemplify the General Directorate for Architecture, Urbanism, and Land Relations of the Chisinau Municipal Council. One of the basic tasks according to the Regulation of the Directorate is the record of the cultural heritage on Chisinau's territory for its use, protection, and conservation, control of compliance with the legislation in the protected areas of historical monuments within their capitalization [19]. The implementation of protection measures consists of the restoration, exploitation, and preservation of monuments of history, culture, and architecture.

Lately, there has been increased involvement of local public authorities in the development of tourism. With the help of central public authorities and grants from European Union projects, local authorities have achieved remarkable results in rebuilding objectives of historic and cultural value. Belecciu Ştefan has stated that the state encourages the activity of public foundations and private individuals, who aim to highlight and use the monuments and their protection zones, thereby trying to bring some incomes and even investments in tourist areas for infrastructure formation and capitalization of the treasures of history and culture ([4], p.59).

\section{Conclusions}

Caring for cultural heritage in the modern world is regarded as an indicator of the maturity of society, the level of its culture, civilization. That is why each country is obliged to take measures to protect its historic and cultural heritage and to create opportunities to familiarize with this heritage of other nations or other generations.

What we have today for us, as an architectural heritage and as historical testimonies left by our ancestors, must pass, as a legacy, to our descendants. This must be done for a continuation of the history of the nation and our own culture, as well as what we can protect now, to leave to future generations, the architectural cultural heritage at least in the state in which we received it from our 
ancestors. And for this, the state must have under its subordination certain institutions, which should capitalize on the architectural cultural heritage, by protecting it, through legal levers. But history shows us that things in this area have often been unfavourable to the protection of architectural heritage.

Over time, political regimes have ruled the organs of public administration, which intentionally or unconsciously have negatively influenced concerning the values of cultural heritage. The unjust actions of the public authorities reside in the destruction, deterioration of historical buildings, religious buildings, or art monuments. We accept the opinion of the authors Dulschi I. and Comendant V. who stated that "regardless of the reasons, in essence, the authorities have carried out the political command to distort the historical past, the ethnic identity, by undermining the fundamental values of the nation, such as language, traditions, customs, etc." ([5], p. 37)

Thus, through their actions, the public authorities have produced effects on several generations in the formation of the national consciousness, depriving them of the possibility of knowing the national cultural values and, respectively, of transmitting this heritage to future generations.

We must borrow the experience in this field from the economically developed countries (e.g. the United Kingdom of Great Britain, Germany, France, Japan, etc.) for which the management of cultural heritage is a model of efficiency, both in terms of economic indicators, but also of the role it has in educating the population and developing the respective society by increasing cohesion and developing stronger communities ([5], pp. 38-39). An eloquent example is an appreciable way in which the respective states capitalize on historical and architectural monuments.

There is also the legal framework on the protection of cultural heritage that needs to be completed, based on the current situation created in terms of cultural heritage. We do not conclude that the legislation of our state is bad. But the fact that certain plans are missing (local, regional, urban), can endanger the protection of the built historic environment and monuments. In this context, our country may even compromise the commitments assumed by the Republic of Moldova to sign several international documents, such as the Convention for the Protection of Architectural Heritage, adopted in 1985 (ratified in 2001) and the European Landscape Convention, adopted in Florence, 2000 (ratified on 14.03.2002).

And the shortcomings in the implementation of the legal framework on cultural heritage in the Republic of Moldova depend not only on the deficiencies and gaps in the legislative and regulatory framework of the specific sector, but also on the level of compatibility and implementation of the legislative framework on public administration.

Currently, under such conditions, we conclude that the state must implement some complex measures, as an efficient way of regularizing the situation, to capitalize and protect the architectural heritage. This thing should 
be done by clearly establishing the circle of institutions, which will have competencies established by normative acts, and the main obligation of which will be the preservation and protection of that part of the cultural heritage, which is a source of remembrance, collective memory, and knowledge that strengthens our common sense of belonging to the nation and the country.

The perspective research plan in the investigation of the topic is directed towards the continuation of the investigations regarding the legislation of the Republic of Moldova concerning the architectural heritage, the issues encountered in the legislation, the positive experience of other states, and the elaboration of proposals for improving the legislation.

\section{Funding Note}

This Research Paper was written within the Research project: Increasing the value of architectural heritage of $R$. Moldova 20.80009.0807.34.

One of the objectives of the research project is the comparative analysis of national and international regulations and policy initiatives on the protection and enhancing of architectural heritage. The main objective in this case, no doubt, must be the corresponding amendment of the national legislation in force.

\section{Conflicts of Interest}

The authors declare no conflicts of interest.

\section{References}

[1] Avram, A., Babeş, M. and Badea, L. (2001) Istoria românilor, vol. I: Moştenirea timpurilor îndepărtate. Editura Enciclopedică, București.

[2] Ploșniță, E. (2013) Patrimoniu şi patrimoniologie în sistemul educaţional al Republicii Moldova: actualitate şi necesitate. Noi tendințe în protecţia şi promovarea patrimoniului cultural național şi European, Materialele Conferinței ştiințifice, 27-28 septembrie 2013, Pontos, Chișinău, 8-15.

[3] Comendant, V. (2016) Competențele autorităților publice privind protejarea patrimoniului cultural național. Materiale ale Conferinței internaționale științifico-practice, Chisinau, 2-3 iunie 2011, 101-105. http://dspace.aap.gov.md/bitstream/handle/123456789/163/101-105.pdf? sequence= 1\&isAllowed $=\mathrm{y}$

[4] Belecciu, Ş. (2007). Aportul autorităților publice la protejarea valorilor culturale. În: Protectia juridică a valorilor culturale din RM. Materialele Conferinței ştiințificopractice internaționale, 21-22 septembrie 2007, 58-61.

[5] Dulschi, I. and Comendant, V. (2016) Contribuția autorităților administrației publice la dezvoltarea şi valorificarea patrimoniului cultural național. Moldoscopie, nr. $4,37-46$.

[6] Law No. 1530 of 22.06.1993 Regarding the Protection of Monuments. In the Official Gazette No. 1din 30.01.1994.

[7] The Constitution of the Republic of Moldova of 29.07.1994. Republished: 29.03.2016 in the Official Gazette No. 78, Art No: 140. Date of Entry into Force: 27.08.1994

[8] (2017) Law on the Protection of Historical Monuments. Law Project. 
https://particip.gov.md/ro/document/stages/proiect-hg-cu-privire-la-aprobarea-pro iectului-legii-protejarii-monumentelor-istorice/4609

[9] Anatolie, S. and Tatiana, B. (2018) Cadru legislativ privind protecția monumentelor de arhitectură în Republica Moldova și în alte state. Conferința UTM2017, vol. II, 400-403.

http://repository.utm.md/bitstream/handle/5014/497/Conf UTM 2017 II pg400-4 03.pdf? sequence $=1$ \&isAllowed $=\mathrm{y}$

[10] Wikipedia (n.d.) Registrul monumentelor Republicii Moldova ocrotite de stat. https://ro.wikipedia.org/wiki/Registrul monumentelor Republicii Moldova ocroti te de stat

[11] Budianschi, D., Stafii, A., Șonțu, G. and Reabcinschi, V. (2013) Evaluarea eficienței și transparenței utilizării resurselor publice alocate culturii.

https://www.expert-grup.org/en/biblioteca/item/download/986 838c36e2842bfbfb7 5f95d57f10a368c

[12] Ministry of Culture, Moldova (2014) Registrul Monumentelor Republicii Moldova. https://date.gov.md/ckan/dataset/5180-registrul-monumentelor-republicii-moldova

[13] Law No. 136 of 07.07.2017 Regarding the Government, Published: 19.07.2017 in the Official Gazette No. 252 Art Nr: 412

[14] Culture Law No. 413-XIV of 27.05.99, Official Gazette of the Republic of Moldova no. $83-86 / 401$ of 05.08 .1999 , Art. 17

[15] Government Decision No. 73 of 31.01.2014, on the Approval of the Regulation on the Organization and Functioning of the National Council of Historical Monuments, Published: 07-02-2014 in the Official Gazette No. 27-34 Art. 87

[16] Government Decision No.1114 of 25.09.2006 on the Creation of the Agency for Inspection and Restoration of Monuments, Published: 29-09-2006 in the Official Gazette No. 153-156 Art. 1191

[17] Order No. 232 of 02.08.2010 Regarding the Approval of the Regulation of the Agency for Inspection and Restoration of Monuments, Published: 03.09.2010 in the Official Gazette no. 155-158 art Nr: 563

[18] Law on Local Public Administration No. 436 of 28-12-2006. Published: 09-03-2007 in the Official Gazette No. 32-35 Art. 116

[19] (2006) Regulation of the General Directorate of Architecture, Urbanism and Land Relations of the Chisinau Municipal Council.

https://chisinau.md/pageview.php? $1=$ ro\&idc $=461 \& i d=1239$ 